\title{
Pender Sağlığı Geliştirme Modeline Göre Tip 1 Diyabet Tanısı Alan Çocuk ve Ailesinin Tanılama Süreci: Olgu Sunumu
}

\section{Arş. Gör. Edanur TAR', Doç. Dr. Sibel KÜçÜKOĞLU²}

'Osmaniye Korkut Ata Üniversitesi Sağlık Bilimleri Fakültesi Hemşirelik Bölümü, OSMANiYE

${ }^{2}$ Selçuk Üniversitesi Hemşirelik Fakültesi Çocuk Sağlığı ve Hastalıkları Hemşireliği Anabilim Dalı, KONYA

\section{Olgu Sunumu}

\section{Sorumlu Yazar}

EdanurTar edanurtar.1107@gmail.com

\section{Edanur Tar}

ORCID: 0000-0001-8821-8554

\section{Sibel Küçükoğlu}

ORCID: 0000-0003-3269-445X

Geliş tarihi: 06.07.2021

Kabul tarihi: 26.07.2021

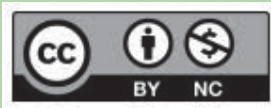

Özet

Çocukluk çağının en sık görülen endokrin ve metabolik hastalıkları arasında yer alan Tip 1 diyabet çocuk ve ailesi üzerinde birçok olumsuz etki yaratmaktadır. Tip 1 diyabeti olan çocukların kan glikoz düzeylerinin optimizasyonu ve komplikasyon riskinin azaltılmasında yapılandırılmış bir öz-yönetim planının izlenmesi gerekmektedir. Bu plan çerçevesinde diyabet yönetiminde günlük kan şekeri takibi, insülin enjeksiyonu, sağlıklı beslenme ve fiziksel aktivite gibi sağık davranışları yer almaktadır. Ancak birçok çocuk ve ailesi diyabet yönetiminde bu sağlık davranışlarına uyum sağlayamamaktadır. Çocuk ve ailesine diyabet yönetim becerilerinin kazandırımasında hemşirelerin rolü oldukça önemlidir. Bu aşamada hemşireler tarafından kuram ve modellerin kullanımı bakımın kalitesini ve profesyonelliği artırmaktadır. Tip 1 diyabeti olan çocuk ve ailesinin Pender'in Sağlı̆̆ı Geliştirme Modeli doğrultusunda değerlendirilmesi diyabet yönetiminde sağlık davranışlarındaki eksikliklerin saptanması ve bu davranışların kazandırılmasında hemşirelere yol gösterici olacaktır. Bu olgu sunumunda Tip 1 diyabeti olan çocuğun düzenli kan şekeri kontrolü, güvenli insülin enjeksiyonu uygulaması, uygun diyet ve fiziksel aktivite gibi sağlık davranışlarının Pender Sağığı Geliştirme Modeli doğrultusunda hemşirelik tanısı koyma süreci ele alınmıştır.

Anahtar Sözcükler: Çocuk; Hemşirelik; Sağlığı Geliştirme Modeli; Tip 1 Diyabet

\section{Summary}

Diagnosis Process of the Child and Family Diagnosed with Type 1 Diabetes According to the Pender Health Promotion Model: A Case Report

Type 1 diabetes, which is among the most common endocrine and metabolic diseases of childhood, has many negative effects on the child and their family. A structured self-management plan should be followed to optimize blood glucose levels and reduce the risk of complications in children with type 1 diabetes. Within the framework of this plan, health behaviors such as daily blood sugar monitoring, insulin injection, healthy nutrition and physical activity are included in diabetes management. However, many children and their families cannot adapt to these health behaviors in diabetes management. At this stage, the use of theories and models by nurses increases the quality of care and professionalism. Evaluation of the child with type 1 diabetes and his/ her family in line with Pender's Health Promotion Model will guide nurses in determining the deficiencies in health behaviors in diabetes management and gaining these behaviors. In this case report, the nursing diagnosis process of the child with Type 1 diabetes, such as regular blood sugar control, safe insulin injection practice, appropriate diet and physical activity, in line with the Pender Health Promotion Model is discussed.

Keywords: Child; Nursing; Health Promotion Model; Type 1 Diabetes

\section{Giriş}

Tip 1 Diyabet, pankreas langerhans adacıklarında bulunan insülin sekresyonundan sorumlu beta hücrelerinin otoimmün veya idiyopatik olarak yıkımı sonucunda gelişen kronik bir hastalıktır. Bu hastalık insülin sekresyonunda bozukluk nedeniyle ortaya çıkan kandaki yüksek glikoz seviyeleri ile karakterizedir (Amerıcan Diabetes Assocıatıon, 2017; Norris, Johnson ve Stene, 2020). Tip 1 diyabet, herhangi bir yaşta 
görülebilmesine rağmen çocukluk ve ergenlikte daha sık karşımıza çıkmaktadır (Norris vd., 2020). Uluslararası Diyabet Federasyonu'na (2019) göre dünya çapında 15 yaş altı 600.900 ve 20 yaş altı 1.110 .100 çocuk Tip 1 diyabet ile yaşamını sürdürmektedir. Ayrıca her yıl 15 yaş altı 98.200 çocuğun Tip 1 diyabet tanısı aldığı ve bu rakamın 20 yaş altında 128.900'e çıktığı bildirilmektedir (Patterson vd., 2019).

Çocukların insülin yetersizliğine yetişkinlerden daha duyarlı olmaları onları şiddetli hipoglisemi ve diyabetik ketoasidoz açısından yüksek risk altına sokmaktadır. Bu durum yapısal beyin anormallikleri ve bilişsel fonksiyonlarda bozukluğa neden olurken akademik yaşamlarını da sınırlayabilmektedir (Ferguson vd., 2005; Patterson vd., 2019). Tip 1 diyabeti olan çocukların, kan glikoz düzeylerinin optimizasyonu ve komplikasyon riskinin azaltılması için günlük kan şekeri takibi, insülin enjeksiyonu, sağlıklı beslenme ve fiziksel aktiviteyi içeren yapılandırılmış bir öz-yönetim planı izlemesi gerekmektedir (Chiang vd., 2018). Aksi taktirde kötü metabolik kontrol hipoglisemi, ketoasidoz gibi akut komplikasyonlara, mikrovasküler ve makrovasküler kronik komplikasyonlara ve ölüme neden olabilmektedir (Chiang vd., 2018; Kanadlı, Sazak ve Olgun, 2020; Patterson vd., 2019). Aynı zamanda birçok çocuk ve ergen Tip 1 diyabetin psikososyal etkileri ile baş etmekte zorlanmakta, hastalığından utanmakta, ve sosyal ilişkilerini kısıtlandırmaktadır (Delamater vd., 2018; Patterson vd., 2019). Tip 1 diyabetin etkin bir şekilde yönetimi yaşam kalitesini artırmakta ancak birçok çocuk ve ailesi diyabet yönetimine uyum sağlayamamaktadır. Çocuk ve ailesine diyabet yönetim becerilerinin kazandııılmasında başta hemşireler olmak üzere tüm sağlık profesyonellerine ciddi bir sorumluluk düşmektedir (Çövener ve Ocakçı, 2013; Wherrett vd., 2018).

Hemşirelerin hastalarına kuram ve modellere dayalı bakım sunması hem bakımın kalitesini artırmakta hem de profesyonelliği sağlamaktadır. Bu modellerden biri olan Pender'in Sağlığı Geliştirme Modeli (SGM) çocuk ve ailenin değerlendirilmesi sağlıklı yaşam tarzını geliştirmek için davranışsal danışmanlığın temeli olarak sağlık davranışlarının temel belirleyicilerini anlamada hemşirelere rehberlik etmektedir (Şişman, 2017).

Bandura'nın Sosyal Öğrenme Kuramı́ndan esinlenilerek geliştirilen SGM bireyin sağlığı geliştiren davranışları üzerinde bilişsel süreçlerin etkisini açıklamaktadır (Çövener, 2013). Modelin temelinde bireyleri sağlıklı yaşam biçimi davranışlarının önemi konusunda bilinçlendirme yer almaktadır. Modele göre bireyler bütüncül olarak değerlendirilmeli ancak parçalarda bütün bağlamında ele alınmalıdır. Bireyler gereksinimleri ve amaçlarını karşılamak için çevrelerini değiştirebilmektedir. Modelin teorik temeli, bireylerin sonuçlarına kıymet verdiği amaçları gerçekleştirmek için daha istekli olduğunu savunan "Beklenti Değer Teorisi (Feathrer)" ile düşünce, davranış ve çevrenin bir etkileşim içinde olduğu, düşünceler doğrultusunda çevrenin şekillendirebileceğini savunan "Sosyal-Bilişsel-Teoriye (Bandura)" dayanmaktadır (Bahar ve Dilay, 2014; Çövener, 2013; Pender, 2006; Şişman, 2017).

SGM, sağlık davranışının oluşmasını etkileyen temel faktörleri tanımlamaktadır. Modelde Pender sağlığı geliştirme davranışlarını etkileyen faktörleri "Bireysel özellikler ve deneyimler" (biyolojik, psikolojik, sosyokültürel kişisel özellikler ve önceki davranışlarla ilişki),
"Davranışa özgü bilişsel süreçler ve etkileri" (yarar algısı, engel algısı, öz yeterlilik, aktivite ile ilişkili etki, kişilerarası etkiler ve durumsal etkiler) ve "Davranış çıktısı" (davranışa karar verme, acil gereksinimler ve öncelikler, davranış çıktısı) olmak üzere üç grupta toplamıştır. Modelin temel kavramları; insan, çevre, hemşirelik, sağlık ve hastalıktır. Hemşireler hizmet verdiği bireylerle işbirliği içinde SGM'yi kullanarak sağlıklı yaşam biçiminin oluşturulmasında davranış değişikliğine yardımcı olabilmektedir (Çövener, 2013; Bahar ve Dilay, 2014; Pender, 2006; Şişman, 2017).

Model bir çok kronik hastalığı olan bireylerde hemşirelere rehberlik etmiştir. Bu nedenle Tip 1 diyabeti olan çocuğun bireysel özellikleri ve geçmişte diyabetin yönetimine yönelik davranışlarını belirlemekte başarılı bir şekilde kullanılabilir. Aynı zamanda çocuğun diyabeti etkin yönetebilmesi için aile, arkadaş ve sağlık profesyonelleri gibi kaynakların harekete geçirilmesiyle gerekli sağlık davranışlarının kazanılmasına destek olmaktadır (Gürkan ve Bahar, 2020).

Bu olgu sunumunda Tip 1 diyabeti olan çocuğun düzenli kan şekeri kontrolü, güvenli insülin enjeksiyonu uygulaması, uygun diyet ve fiziksel aktivite gibi sağlık davranışlarının SGM doğrultusunda değerlendirilmesi ve tanılanması amaçlanmıştır.

\section{Olgu}

1.5 yıldır Tip 1 diyabet tanısı alan $27 \mathrm{~kg}$ ve $133 \mathrm{~cm}$ olan 8 yaşında erkek hastada (K.B.A.) ilk şikayet ateş ile başlamıştır. Kan şekeri değerinin 425 mmol/L çıkması üzerine K.B.A.'ya Tip 1 diyabet tanısı konulmuş ve tanı sonrası 8 ay balayı dönemi geçirmiştir. Tanı konulması itibari ile 4 'lü insülin tedavisi başlanmıştır. 3 öğün öncesi kısa etkili“Humolog” gece ise 5 ünite uzun etkili “Lantus” kullanmaktadır. Günde 8 kez kan şekeri ölçümü yapılmaktadır (3 öğün öncesi ve sonrası gece 12'de ve 3'te).

\section{Sağlığı Geliştirme Modeli Doğrultusunda}

Olgunun Değerlendirilmesi

Bu kısımda olgu, modelin üç temel bileşeni olan "Bireysel özellikler ve deneyimler", "Davranışa özgü bilişsel süreçler ve etkileri” ve "Davranış çıktısı" doğrultusunda ele alınmıştır.

Tablo 1: Laboratuvar tetkikleri

\begin{tabular}{l|l|l|l}
\hline Parametreler & \multicolumn{2}{l}{ Sonuç } & \multicolumn{1}{l}{ Normal Sınırlar } \\
\hline Glikoz & $307 \mathrm{mg} / \mathrm{dl}$ & $\uparrow$ & $\begin{array}{l}60-110 \mathrm{mg} / \mathrm{dl} \\
*(>126 \text { Diyabet})\end{array}$ \\
\hline Kolesterol & $253 \mathrm{mg} / \mathrm{dl}$ & $\uparrow$ & $(0-200)$ \\
\hline $\mathrm{HDL}$ & $66.9 \mathrm{mg} / \mathrm{dl}$ & $\mathrm{N}$ & $(>40)$ \\
\hline $\mathrm{LDL}$ & $172.7 \mathrm{mg} / \mathrm{dl}$ & $\uparrow$ & $(0-130)$ \\
\hline C-Peptit & $0.165 \mathrm{ng} / \mathrm{ml}$ & $\uparrow$ & $(1.1-4.4)$ \\
\hline İnülin & $1.37 \mu \mathrm{g} / \mathrm{mL}$ & $\uparrow$ & $(2.6-24.9)$ \\
\hline HbA1C & $9.64 \%$ & $\uparrow$ & $(3.5-5.6)$ \\
& & & $*(>6.5$ Diyabet)
\end{tabular}




\section{Bireysel Özellikler ve Deneyimler}

Çocuğun biyolojik, psikolojik, sosyokültürel faktörler gibi bireysel özellikleri sağlık davranışlarını farklı etkilemektedir. Davranışa yönelik deneyimleri (örneğin düzenli insülin enjeksiyonu yapma veya yapmama) ise sağlığı geliştirme davranışları üzerinde oldukça önemlidir (Alligood ve Tomey, 2010; Pender, 2006).

\section{Bireysel Özellikler}

İnce ve kaba motor becerileri gelişmiş olan K.B.A. kan şekeri ölçümü ve insülin enjeksiyonunu kendi kendine yapabilmektedir. Kısa etkiliyi (Humolog) bacaktan, uzun etkiliyi (Lantus) kalçadan yapmaktadır. Ancak sağ elini kullandığı için enjeksiyonu genelde sağ bacağına yapmakta ve rotasyon tekniğine dikkat etmemektedir. K.B.A. Tip 1 diyabet olduğunu, insülin yapılması gerektiğini, diyetine dikkat etmesi ve düzenli egzersiz yapması gerektiğini bilmektedir. Ancak diyabetin etkin yönetilmediğinde komplikasyonların gelişebileceğini algılayamamakta ve ara ara "Ben şeker hastası değilim, insülin ve diyet yapmayacağım" şeklinde ifadelerde bulunmaktadır. Hastalığın etkileri ve yaşamındaki değişikliklerle yok sayarak baş etmektedir. Bu nedenle kan şekeri yüksek çıktığında "Aman düşer o" şeklinde tepki vermektedir. Bisiklet sürme, futbol oynama gibi aktiviteleri kontrolsüz yapmaktadır. Hipoglisemi durumunda kan şekeri düzeyinin düşük olabileceğini, halsiz olduğunu ifade etmektedir. K.B.A. Tip 1 diyabet tanısı alana kadar nokturnal enürezis yaşamış ancak tedavi sonrasında sona ermiş ve günlük 7-8 kez idrarını yapmaktadır.

Hastalığın aile üzerinde yarattığı psikolojik etkiler incelendiğinde ise; aile bireyleri tüm yaşamlarını çocuğun hastalığına göre düzenlemekte ve çocuk için kaygı duymaktadır. Anne "Bir çocuğu yemek ve içmekle kısıtlamak dünyanın en zor şeyi" şeklinde ifade etmektedir. Anneye göre Tip 1 diyabeti olan insanlar aslında abur cubur tüketmeyen sağlıklı beslenen insanlardır ancak K.B.A.'nın diyetine dikkat etmediğini vurgulamaktadır. Ebeveynlerin K.B.A.'nın hastalığına yönelik bilgilerinin olduğu, komplikasyonları gözlemleyebildikleri ve çocuğun evde bakımını yönetebildikleri görülmektedir. Anne çocuğun hastalığına yönelik yoğun duygular taşımaktadır. "Marketten çocuğuna şeker, çikolata vb. alıp götürememek, çocuğunun bacağının parmaklarının sürekli iğneyle delinmesi çok zor bir durum" şeklinde ifade etmektedir. K.B.A. ile birlikte iş birliği içinde hastalığı yönetmeye çalıştıklarını bazen kan şekeri yüksek çıktığında çok canının sıkıldığını ve sigara içtiğini belirtmektedir. Anne, baba, çocuk arasındaki ilişki çok iyi ve birlikte hoşça vakit geçiriyorlar. Anne K.B.A.'nın pandemi sürecinde online eğitimle

Tablo 2: Açllk kan glikozu takibi

Açlık Kan Glikozu Takibi (3 günlük)

\begin{tabular}{|l|l|l|ll|}
\hline Gün & Sabah & Öğle & Akşam & Gece (00.00) \\
\hline 1.gün & $296 \mathrm{mmol} / \mathrm{L}$ & $170 \mathrm{mmol} / \mathrm{L}$ & $396 \mathrm{mmol} / \mathrm{L}$ & $101 \mathrm{mmol} / \mathrm{L}$ \\
\hline 2. gün & $253 \mathrm{mmol} / \mathrm{L}$ & $57 \mathrm{mmol} / \mathrm{L}$ & $297 \mathrm{mmol} / \mathrm{L}$ & $250 \mathrm{mmol} / \mathrm{L}$ \\
\hline 3. gün & $213 \mathrm{mmol} / \mathrm{L}$ & $206 \mathrm{mmol} / \mathrm{L}$ & $374 \mathrm{mmol} / \mathrm{L}$ & $336 \mathrm{mmol} / \mathrm{L}$ \\
\hline
\end{tabular}

2. Davranışa Özgü Bilişsel Süreçler ve Etkileri

Çocuğun diyabet yönetiminde sağlık davranışlarına özgü algıları bu bölümde değerlendirilmiştir.

Davranışa ilişkin algılanan yararlar: Çocuğun diyabet yönetiminde kazanılması gereken sağlık davranışının olumlu etkilerini bilmesi davranışın başlatılması ve sürdürülmesinde kolaylık sağlamaktadır (Çövener ve Ocakçı, 2013; Pender, 2006). K.B.A. hastalığı ile ilgili kazanması gereken sağlık davranışlarınının diyabetin etkin yönetimi üzerindeki olumlu etkilerini algılayamamaktadır. Örneğin; kan şekeri düzenlemesinin diyabetin uzun dönem komplikasyonlarını (mikrovasküler: retinopati, nefropati, nöropati; makrovasküler: kardiyovasküler bozukluklar, hipertansiyon) önlemede etkili olduğunu kabullenmemektedir. Ancak günlük kan şekeri ölçümü ve insülin enjeksiyonunu yapması gerektiğinin farkındadır. Örneğin; insülini yanında olmadığında dışarda yemek yiyemeyeceğini ifade etmektedir.

Davranışa ilişkin algılanan engeller: Çocuğun davranışa yönelik olumsuz duyguları davranışın gelişimini olumsuz olarak etkileyecektir (Çövener ve Ocakçı, 2013; Pender, 2006). K.B.A.'nın hastalığı ile ilgili kazanması gereken sağlık davranışlarının gelişmesinde bu davranışlarla ilgili olumsuz duyguları bulunmaktadır. K.B.A. hastalığı ile ilgili okulda öğretmenleri ve arkadaşlarından çekinmektedir. Örneğin; okulda kan şekeri düzeyini daha rahat ölçerken insülin enjeksiyonu sırasında pantolonunu indirmesi gerektiğinden müdürün odasında kapıyı kapatarak yapmaktadır. K.B.A. okulda insülin enjeksiyonunu yaparken ailesinden birinin yanında olmasını istemekte öğretmenlerinin yardımcı olma teklifini reddetmektedir.

Algılanan öz yeterlilik: Algılanan öz yeterlilik, çocuğun sağlığı geliştirme davranışını başarılı bir şekilde yapabileceğine ilişkin kendisi hakkındaki inancı şeklinde tanımlanmaktadır (Çövener ve Ocakçı, 2013; Pender, 2006). K.B.A.'nın diyabet yönetiminin sağlığı üzerindeki etkisini algılayamadığı bu nedenle diyet ve egzersize uyum sağlamada başarısız olduğu görülmektedir. Okula giden ve toplu ortamlarda bulunan K.B.A. yaş-gelişim dönemi nedeniyle COVID-19 virüsünden kendini yeterli düzeyde ko- 
ruyamamakta ve enfeksiyona açık hale gelmektedir.

Aktivite ile ilgili etkiler: Çocuğun hastalığı ile ilgili kazanması gereken sağlık davranışı öncesinde, sırasında ya da sonrasında olumlu duygular ve olumlu bakış açısına sahip olma durumu davranışa başlama ve davranışı sürdürmeyi kolaylaştırmaktadır (Çövener ve Ocakçı, 2013; Pender, 2006). K.B.A. kan şekeri seviyesi istenilen düzeyde olduğunda mutlu olmakta ve istediği yemekleri yemekte ancak istenilen düzeyin üstünde olduğunda az yemekte ve mutsuz olmaktadır.

Kişilerarası etkiler: Çocuğun hastalığı ile ilgili kazanması gereken sağlık davranışlarınının kazanılması ve sürdürülmesinde aile, akranlar ve sağlık profesyonellerinin desteğinin oldukça önemli olduğu belirtilmektedir (Çövener ve Ocakçı, 2013; Pender, 2006). Diyabetin yönetiminde K.B.A. ebeveynlerinden destek görmektedir. Ancak anne bu süreçte sağlık profesyonellerinden yeterince destek görmediğini, tanının şokuyla ne yapacağını şaşırdığını ve diyabet hakkında bu kadar ayrıntılı bilgisi olmadığını araştırarak öğrendiğini ifade etmektedir. Okulda arkadaşları tarafından K.B.A.ya kısıtlanan yiyecekler verilmekte ve çocuk da bunları alıp yemektedir.

Durumsal etkiler: Hastalık ile ilgili kazanılması gereken sağlık davranışlarını kolaylaştırabilen ya da engelleyebilen kişisel algılar durumsal etkiler olarak tanımlanmaktadır (Alligood ve Tomey, 2010; Çövener ve Ocakçı, 2013). K.B.A.'nın sensör kullanmak istememesi diyabetin yönetimini zorlaştırmakta ancak ailesinden gördüğü destekle kan şekeri takibi ve insülin enjeksiyonu yapma gibi sağlık davranışlarını sürdürmektedir.

\section{Davranış Çıktısı}

Çocuğun diyabet yönetimine ilişkin gösterdiği sağlık davranış çıktıları bu bölümde değerlendirilmiştir.

Davranışa karar verme: Bu aşamada çocuğun diyabetin yönetimi ile ilgili sağlık davranışlarını gösterebilme, bu davranışlarla ilgili planladığı yöntemleri kendi yaşam biçimine uyarlayabilme ve diyabet yönetimini yeniden planlayabilme durumu değerlendirilmektedir (Alligood ve Tomey, 2010; Çövener ve Ocakçı, 2013). K.B.A. kan şekeri takibi ve insülin uygulamasını yapmakta ancak diyetine uymadığı ve düzenli egzersiz programının olmadığı görülmektedir.

Acil gereksinimler (düşük kontrol) ve öncelikler (yüksek kontrol): Çocuğun sağlık davranışını gerçekleştirmede çevresel faktörlerin de etkisiyle davranışlar üzerinde düşük ve yüksek kontrol sağlama durumunu tanımlamaktadır (Alligood ve Tomey, 2010; Çövener ve Ocakçı, 2013). Ara

Şekil 3: Sağı̆̆̆ı Geliştirme Modeli kavramlarının Tip 1 diyabete uyarlanması (Çövener, 2013)

SAĞLIĞI GELİSTTIRME MODELİ KAVRAMLARININ TİP 1 DİYABETE UYARLANMASI

Bireysel Özellikler ve Deneyimler

Diyabete İliskin
Önceki Deneyimler
(Olumsuz bir deneyim sonrası
sensöre güvenmeme)

Bireysel Özellikler
Biyolojik
(8 yasıında, 1.5 yıldır diyabet
tanısı var, motor becerileri iyi)
Psikolojik
(Diyabeti yok sayma)
Sosyokültürel
(Kültürel beslenme özellikleri)

Davranıșa Özgü Bilişsel Süreçler ve Etkileri

Algılanan Yarar

(Diyabet yönetiminin kısa dönem komp. üzerindeki etkisinin farkında iken uzun dönem komp. algılayamama)

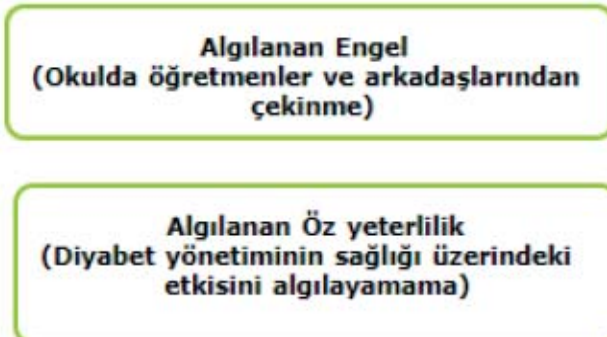

Aktivite ile ilgili Etkiler

(Kan șekeri seviyesi normal aralıkta olduğunda mutlu olma)

Kişilerarası Etkiler

(Diyabet yönetiminde ebeveyn desteği)

\section{Durumsal Etkiler}

(Sensör kullanmak istememesinin

diyabet yönetimini zorlaştırması)

\section{Davranış Çıktısı}

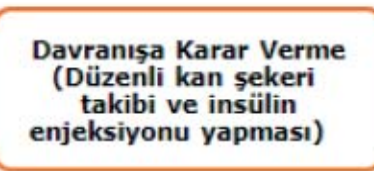

Acil Gereksinimler (Düşük Kontrol)

$$
\text { ve }
$$

Öncelikler

(Yüksek Kontrol)

(Kisitlanan besinlerin

tercih edilmesi düșük

kontrol öğünlerde

karbonhidrat-protein

tüketimine dikkat etmesi yüksek kontrol)

Sağlığı Geliștirme Davranıș (Düzenli egzersiz ve diyet uyumu olmadığından diyabeti etkin yönetememe) 
öğüne meyve konmasına rağmen arkadaşları kek yiyorsa veya meyveli soda içiyorsa K.B.A.'nın da bu besinleri tercih etmesi düşük kontrolü, bir öğünde karbonhidrat içeriği yüksek besinler aldıysa diğer öğünde protein ağırlıkı beslenmeye çalışması, kan şekeri takibi ve insülin enjeksiyon uygulamasını düzenli olarak yapması ise yüksek kontrolü göstermektedir.

Sağlığı geliştirme davranışı: Bu aşamada diyabetin etkin yöne- timini sağlayabilme durumu gibi olumlu sağlık çıktıları değerlendirilmektedir (Alligood ve Tomey, 2010; Çövener ve Ocakçı, 2013; Pender, 2006). K.B.A.'nın diyabetin komplikasyonlarını algılayamaması nedeniyle düzenli egzersiz yapmaması ve diyete uyum sağlayamamasından kaynaklı kan şekerinde dalgalanmalar olması diyabetin yönetimini etkin bir şekilde sürdüremediğini göstermektedir. Modelin kavramları

\section{Hemşirelik Tanıları}

\section{Biyolojik Özellikler, Psikolojik Özellikler, Sosyokültürel Özellikler Ve Davranışa Ilişkin Önceki Deneyimlere Yönelik Hemşirelik Tanıları}

\section{Hemşirelik Tanısı}

Ailede Anksiyete

Enfeksiyon Riski

\section{İlişkili Faktörler (Uyaranlar)}

Çocuğun yaşamını tehdit eden bir hastalığa sahip olması, Çocuğun hastalığından dolayı besin kısıtlamasına gidilmesi, Günlük kan şekeri ölçümü ve insülin enjeksiyonu yapma.

Tip 1 diyabetin etkisiz yönetimine bağlı çocuğun kan şekeri düzeylerinin normal sınırlarda olmaması,

Tip 1 diyabete bağlı hipoglisemi, hiperglisemi, inflamatuar yanitta bozulma,

Günlük 8 kez kan şekeri ölçümü ve 4 kez insülin enjeksiyonuna bağlı invaziv girişimler,

Glikozüri gelişebilme durumu,

Çocuğun okula gitmesi ile toplu ortamlarda bulunması ve yaş-gelişim dönemi nedeniyle COVID-19 virüsünden kendini yeterli düzeyde koruyamaması.

\section{Tanımlayıcı Faktör (Davranış)}

Annenin çocuğun hastalığı ile ilgili konuşurken yoğun duygular taşıdığını belirtmesi, Ebeveynlerin çocuk ile ilgili gelecek kaygısı hissetmesi, Annenin "Bir çocuğu yemek ve içmekle kısıtlamak dünyanın en zor şeyi" şeklinde ifadesi ve bu duruma çok üzülmesi, Çocuğun kan şekeri normalin üzerinde çıktığında annenin çok endişe duyması ve sigara içmesi.

\section{Davranışa Özgü Bilișsel Süreçler ve Etkilerine Yönelik Hemșirelik Tanıları}

\section{Hemşirelik Tanısı \\ Etkisiz İnkâr}

Benlik Kavramında

Rahatsızlık

\section{Ilişkili Faktörler (Uyaranlar)}

Çocuğun hastalığı ile ilgili kazanması gereken sağlık davranışlarının diyabetin etkin yönetimi üzerindeki olumlu etkilerini algılayamaması,

Somut işlemsel dönemde olmaya bağlı kan şekeri düzenlemesinin diyabetin uzun dönem komplikasyonlarını önlemede etkili olduğunu kabullenmeme.

Tip 1 diyabete bağlı kendisini akranlarından farklı hissetmesi.

\section{Tanımlayıcı Faktör (Davranış)}

Annesi kan şekeri yüksek olduğunda uyardığında "Aman düşer o" şeklinde tepki vermesi, Bazen kan şekeri takibi ve insülin enjeksiyonunu düzenli yapması ancak ara ara "Ben şeker hastası değilim, insülin ve diyet yapmayacağım" ifadesi.

\section{Okulda enjeksiyon yaparken öğretmenleri ve} arkadaşları tarafından görülmesi ve arkadaşlarından farklı besinlerle beslenmesinden kaynaklanan utanç duygusu,

Hastalığın inkar edilmesi. 
Tip 1 Diyabetin değerledirilmesi ile ilgili Şekil 3'de somutlaştırılmıştır.

Bu olgu sunumunda Tip 1 diyabeti olan çocuk SGM doğrultusunda değerlendirilmiş ve NANDA sınıflama sistemine göre aşağıda belirtilen hemşirelik tanılarına gereksinimi olduğu saptanmıştır.

\section{Sonuç}

Tip 1 diyabeti olan birçok çocuk ve ailesi hastalığın getirdiği olumsuz etkilerle karşı karşıya kalmakta ve diyabetin etkin yönetimini sağlayamamaktadır. Çocuk ve ailesine diyabet yönetim becerilerinin kazandırılmasında hemşireler kilit noktada rol almaktadır. Bu aşamada hemşireler tarafından standardize edilmiş kuram ve modellerin kullanımı bakımın kalitesini ve profesyonelliği artırmaktadır. Tip 1 diyabeti olan çocuk ve ailesinin, diyabet yönetiminde mevcut sağlık davranışlarındaki eksikliklerin saptanması ve bu davranışların kazandırılmasında SGM hemşirelere rehberlik etmektedir. SGM doğrultusunda değerlendirilen olguda; K.B.A.'nın diyabet yönetiminde sağlık davranışlarından düzenli kan şekeri ölçümü ve insülin enjeksiyonunu yaptığı ancak diyet ve egzersiz uyumunun olmadığı bu nedenle kan şekeri düzeylerinde dalgalanmalar olduğu saptanmıştır.

Bilgilendirilmiş Onam: Olgu sunumunun yayınlanması hususunda K.B.A. ve ailesi bilgilendirilerek yazılı ve sözlü onam alınmıştır.

\section{Kaynaklar}

1. Alligood, M. R., Tomey, A. M. (2010). Nursing theorists and their work. 7th ed. Mosby, USA. p.434-454.

2. American Diabetes Association. (2017). 2. Classification and diagnosis of diabetes. Diabe- tes care, 40(Supplement 1), p.11-24.

3. Bahar, Z., Dilay, A. (2014). Sağlığı geliştirme modeli: kavramsal yapı, Dokuz Eylül Üniversitesi Hemşirelik Fakültesi Elektronik Dergisi, 7(1), 59-67.

4. Chiang, J. L., Maahs, D. M., Garvey, K. C., Hood, K. K., Laffel, L. M., Weinzimer, S. A., Schatz, D. (2018). Type 1 diabetes in children and adolescents: a position statement by the American Diabetes Association, Diabetes Care, 41(9), 2026-2044.

5. Çövener, Ç. (2013). Sağlığı geliştime modeli. AF Ocakçı (Ed.), ŞE Alpar (Ed.), Hemşirelikte kavram, kuram ve model örnekleri. 1. Baskı. İstanbul: İstanbul Tıp Kitabevi.

6. Çövener Ç. Ö., Ocakçı, A. F. (2013). Tip 1 diyabet yönetimi: bir hemşirelik modeli örneği, Hemşirelikte Eğitim ve Araştırma, 10(1), 30-37.

7. Delamater, A. M., de Wit, M., McDarby, V., Malik, J. A., Hilliard, M. E., Northam, E., \& Acerini, C L. (2018). ISPAD Clinical Practice Consensus Guidelines 2018: Psychological care of children and adolescents with type 1 diabetes, Pediatric Diabetes, 19, 237-249.

8. Ferguson, S. C., Blane, A., Wardlaw, J., Frier, B. M., Perros, P., McCrimmon, R. J., \& Deary, I. J. (2005). Influence of an early-onset age of type 1 diabetes on cerebral structure and cognitive function, Diabetes care, 28(6), 1431-1437.

9. Gurkan, K. P., Bahar, Z. (2020). Structuring the Home Care of Adolescents with Type I Diabetes According to the Health Promotion Model, Journal of Education and Research in Nursing, 17(1), 121-126.

10. Kanadll, A. K., Sazak, Y., Olgun, N. (2020). COVID-19 pandemisinde Tip 1 diyabet hastasının Orem Öz Bakım Teorisi'ne göre değerlendirilmesi: olgu sunumu, Diyabet, Obezite ve $\mathrm{Hi}$ pertansiyonda Hemşirelik Forumu Dergisi, 12(2), 57-62.

11. Norris, J. M., Johnson, R. K., Stene, L. C. (2020). Type 1 diabetes-early life origins and changing epidemiology, The Lancet Diabetes \& Endocrinology, 8(3), 226-238.

12. Patterson, C. C., Karuranga, S., Salpea, P., Saeedi, P., Dahlquist, G., Soltesz, G., \& Ogle, G. D. (2019). Worldwide estimates of incidence, prevalence and mortality of type 1 diabetes in children and adolescents: Results from the International Diabetes Federation Diabetes Atlas, Diabetes Research and Clinical Practice, 157, 107842.

13. Pender, N. J., Murdaugh, C. L., Parsons, M. A. (2006). Health promotion in nursing practice 5th ed. Pearson Prentice Hall, USA. p.47-67.

14. Şişman, N. Y. (2017). Nola J. Pender: Sağlığı geliştirme modeli. A Karadağ (Ed.), N Çalışkan (Ed.), ZG Baykara (Ed.), Hemşirelik teorileri ve modelleri. 1. Baskı. İstanbul: Akademi Basın. s.638-652.

15. Wherrett, D. K., Ho, J., Huot, C., Legault, L., Nakhla, M., Rosolowsky, E. (2018). Type 1 diabetes in children and adolescents, Canadian Journal of Diabetes, 42, 234-246.

\section{Davranış Çıktısına Yönelik Hemşirelik Tanıları}

\section{Hemşirelik Tanısı}

Sağlığı Etkisiz Yönetme

\section{Kan Glikozunda \\ Değişkenlik Riski}

Doku Bütünlüğünde

Bozulma Riski

\section{ilişkili Faktörler (Uyaranlar)}

Çocuğun bulunduğu yaş ve gelişim dönemine özgü diyabetin etkin yönetilmediğinde ortaya çıkabilecek uzun süreli komplikasyonları algılayamaması, Okulda arkadaşları ve öğretmenlerinden çekinme,

Diyabetin yönetimini kolaylaştırabilecek araç gereçlere (sensör, insülin pompası) güvenmeme.

Diyabete ilişkin diyetine uymama, düzenli egzersiz yapmama, bisiklet sürme, futbol oynama gibi aktiviteleri kontrolsüz yapma, Yaş ve gelişim dönemine bağlı olarak diyabetin uzun dönem komplikasyonlarını algılayamama. Günde 8 kez kan şekeri ölçümü ve 4 kez insülin enjeksiyonu yapması, Enjektörü sağ elle tuttuğu için genelde sağ bacağa yapmak istemesi, rotasyon tekniğine dikkat etmemesine bağlı lipodistrofi gelişme olasılığı.

\section{Tanımlayıcı Faktör (Davranış)}

Diyabeti yönetmede kan şekeri takibi ve insülin enjeksiyonunu yapması ancak diyet ve egzersize dikkat etmemesi, okulda arkadaşları kısıtlı olan yiyecekleri verdiğinde alıp yemesi, Arkadaşları kantinden kek, meyveli soda aldığında onun da bu besinleri tercih etmesi,

Kan şekeri ölçümü için alınan sensörü yapılan ölçüme güvenmeme, öğretmeni ve arkadaşlarının görmesinden çekinme, anne baba tarafından kan şekeri düzeyinin kontrol edilmesini istememe gibi nedenlerden dolayı kullanmama, Kan şekerinde sürekli dalgalanmalar olması. 